\title{
Nutrition and production of coconut palm cultivated with mineral fertilization in the state of Pará
}

\author{
Paulo Manoel Pontes Lins ${ }^{1}$, Ismael de Jesus Matos Viegas², \\ Eric Victor de Oliveira Ferreira ${ }^{3}$
}

\begin{abstract}
Fertilization greatly affects coconut productivity; nevertheless, information on crop nutrition is relatively scarce for coconut in the state of Pará, Brazil. This study evaluated the effect of fertilization with nitrogen $(\mathrm{N})$, phosphorus $(\mathrm{P})$, potassium $(\mathrm{K})$, and magnesium $(\mathrm{Mg})$ on the nutritional status and coconut yield under the edaphoclimatic conditions of the municipality of Moju, Pará State (Brazil). The experiment was conducted for 10 years on a $\mathrm{SOCOCO}^{\circledR}$ Farm and used a randomized block design with three replications. Three levels of $\mathrm{P}, \mathrm{K}$, and $\mathrm{Mg}$ were used in presence and absence of $\mathrm{N}$. Response to fertilization in the treatments was studied in terms of leaf concentration of macronutrients $(\mathrm{N}, \mathrm{P}, \mathrm{K}, \mathrm{Ca}, \mathrm{Mg}$ and $\mathrm{S})$ and micronutrients $(\mathrm{B}$ and $\mathrm{Cl})$. We also assessed the number of coconuts/plant/year, fresh albumen weight (FAW)/coconut and FAW/ ha/year. The results were subjected to the analysis of variance $(\mathrm{p}<0.05)$ and the means compared by the Tukey test. In general, $\mathrm{N}$ fertilization did not influence concentration of macronutrients and micronutrients in leaves. In turn, $\mathrm{P}, \mathrm{K}$ and $\mathrm{Mg}$ fertilization influenced nutrition of coconut palm. $\mathrm{P}$ and $\mathrm{K}$ fertilizations, isolated or in combination, increased the production of coconut/plant and FAW/ha. From the $6^{\text {th }}$ year of plant age, $54 \mathrm{~kg} / \mathrm{ha} /$ year of $\mathrm{P}_{2} \mathrm{O}_{5}$ and $96 \mathrm{~kg} / \mathrm{ha} /$ year of $\mathrm{K}_{2} \mathrm{O}$ are indicated for the coconut culture in the region of the current study. $\mathrm{N}$ fertilization did not influence production parameters and $\mathrm{Mg}$ fertilization increased production in the presence of K fertilization. Indexing Terms: Amazon, Cocos nucifera L., macronutrients.
\end{abstract}

\section{Nutrição e produção de coqueiro cultivado com adubação mineral no estado do Pará}

Corresponding author: pmplins@uol.com.br

Received: September 02, 2020 Accepted: May 04, 2021

Copyright: All the contents of this journal, except where otherwise noted, is licensed under a Creative Commons Attribution License.

\section{(cc) $\mathbf{E Y}$}

Resumo- A adubação é a prática que tem maior impacto na produtividade do coqueiro; ainda assim, as informações sobre a nutrição da cultura são relativamente escassas no Estado do Pará. O presente estudo objetivou avaliar o efeito das adubações nitrogenada, fosfatada, potássica e magnesiana sobre o estado nutricional e a produção do coqueiro nas condições edafoclimáticas de Moju (PA). O experimento foi conduzido durante dez anos, na fazenda $\mathrm{SOCOCO}^{\circledR}$, e utilizou-se do delineamento em blocos ao acaso, com três repetições, e três níveis de $\mathrm{P}$, três níveis de $\mathrm{K}$ e três níveis de $\mathrm{Mg}$, na presença e na ausência de $\mathrm{N}$. A resposta à aplicação dos tratamentos foi estudada em termos de concentração foliar dos macronutrientes (N, P, K, Ca, Mg e S) e dos micronutrientes $(\mathrm{B} \mathrm{e} \mathrm{Cl})$, e da produção do número de cocos/planta/ano, peso de albúmen fresco (PAF)/coco e PAF/ ha/ano. Os resultados foram submetidos à análise de variância $(\mathrm{p}<0,05)$; e as médias, comparadas pelo teste de Tukey. De forma geral, a aplicação de $\mathrm{N}$ não influenciou as concentrações foliares dos macronutrientes e dos micronutrientes estudados. Por sua vez, as adubações fosfatada, potássica e magnesiana influenciaram a nutrição das plantas de coqueiro. As adubações fosfatada e potássica, isoladamente ou em interação, aumentaram a produção de cocos/planta e o PAF/ha. A partir do $6^{\circ}$ ano de idade das plantas, os níveis de $54 \mathrm{~kg} / \mathrm{ha} /$ ano de $\mathrm{P}_{2} \mathrm{O}_{5}$ e $96 \mathrm{~kg} / \mathrm{ha} /$ ano de $\mathrm{K}_{2} \mathrm{O}$ são indicados para o cultivo do coqueiro na região da presente pesquisa. A adubação nitrogenada não influenciou os parâmetros de produção, e a adubação magnesiana aumentou a produção na presença da adubação potássica.

Termos para Indexação: Amazônia, Cocos nucifera L., macronutrientes.

\footnotetext{
${ }^{1} \mathrm{PhD}$ in Agricultural Sciences, Agricultural Superintendent at the Reunidas Sococo Company. Santa Isabel do Pará- PA, Brazil, E-mail: pmplins@uol.com.br(ORCID 0000-0003-3900-7261)

${ }^{2} \mathrm{PhD}$ in Soil and Plant Nutrition, Professor at the Universidade Federal Rural da Amazônia (UFRA)- Campus Capanema, Capanema- PA, Brazil. Email: matosviegas@hotmail.com (ORCID 0000-0001-7212-1977)

${ }^{3} \mathrm{PhD}$ in Soil and Plant Nutrition, Professor at UFRA- Campus Capitão Poço, Capitão Poço-PA, Brazil. E-mail: ericsolos@yahoo.com.br ${ }^{(0 R c ı d ~}$
} 0000-0003-0142-8466) 


\section{Introduction}

Coconut palm (Cocos nucifera L.) is an important crop for food security and income generation, as well as the production of many products (LINS and VIEGAS, 2008); thus, coconut has become an important agricultural activity for the Brazilian economy (FRÓES JÚNIOR et al., 2019). Areas cropped with coconut palms reach roughly 12 million ha worldwide and Indonesia, the Philippines, and India account for $73 \%$ of global production (FAOSTAT, 2018), yielding income through the export of coconut copra and oils (BRAINER, 2018).

Coconut crops in Brazil cover roughly 216,000 ha. The northeastern region accounts for $74 \%$ of the national production, southeastern region responds for $13 \%$, and the northern region accounts for $12 \%$ (IBGE, 2018). In the northern region, the state of Pará has the largest area cropped with coconut in the country, totaling 18,600 ha, accounting for $93 \%$ of production with an average yield $9.35 \mathrm{t} / \mathrm{ha}$ (IBGE, 2018). The municipality of Moju alone accounts for $43 \%$ of the production in Pará State, with the world's largest continuous area of coconut cultivation (FRÓES JÚNIOR et al., 2019). Therefore, the state of Pará has great potential in the coconut farming due to its edaphoclimatic characteristics, availability of rural credit, and knowledge of the activity at the commercial level (FRÓES JÚNIOR et al., 2019).

Most coconut palm farms in Pará still operate with low investments, reflecting in low yields (LINS and VIEGAS, 2008), despite a highly technical production system, due to the presence of large commercial groups (FRÓES JÚNIOR et al., 2019). Mineral fertilization is used to promote growth and increase crop yield of coconut palm; however, information on this practice is scarce for the conditions in Pará (LINS and VIEGAS, 2008). Although soil fertility is not a limiting factor for coconut palm, fertilization greatly affects its yield (SOBRAL, 1998; SILVA et al., 2006; SILVA et al., 2009). Coconut trees have continuous growth, demanding large amounts of soil nutrients (RIBEIRO et al., 2016) that must be replenished by fertilization. Studies carried out in Brazil have evaluated mainly the response of coconut palm to $\mathrm{N}$ and $\mathrm{K}$ fertilization (SILVA et al., 2006; SILVA et al., 2009; RIBEIRO et al., 2011), but not to $\mathrm{P}$ and $\mathrm{Mg}$ applications. The coconut tree demands large amounts of $\mathrm{K}$ and, over the years, $\mathrm{K}$ fertilization may induce $\mathrm{Mg}$ deficiency in plants by antagonism (LIMA et al., 2018), a symptom commonly observed in coconut plantations. Thus, the balance of $\mathrm{K}$ and $\mathrm{Mg}$ supply for the coconut tree is of great importance, also justifying studies on $\mathrm{Mg}$ fertilization.
Despite recommendations (LINS and VIEGAS, 2020), liming is not a common practice in coconut plantations in the state of Pará; however, $\mathrm{Ca}$ is already normally supplied via P sources (superphosphates or natural phosphate).

The nutritional status of coconut trees affects its vegetative growth, volume, and production (MATIAS et al., 2006; FERREIRA NETO et al., 2014). An adequate nutritional balance can increase coconut production by up to $125 \%$ (SECRETARIA and MARAVILLA, 1997). Thus, nutritional monitoring with the leaf analysis is an efficient fertilization method of coconut crops (SALDANHA et al., 2017), as observed for the state of Pará (LINS and VIEGAS, 2020). However, results on mineral nutrition in coconut palm crops are not commonly reported in the scientific literature in Brazil (LINS and VIEGAS, 2008) and may also vary depending on the coconut genotype (giant or hybrid) (ROGNON, 1984), requiring specific studies under the conditions of each region.

The objective was to evaluate the effects of $\mathrm{N}$, $\mathrm{P}, \mathrm{K}$, and $\mathrm{Mg}$ fertilization on the nutritional status and coconut production; therefore, an experiment was carried out in the edaphoclimatic conditions of Moju, Pará State, to provide information on crop fertilization in the region.

\section{Material and Methods}

The experiment was carried out at the property of SOCOCO S/A Group, located in the municipality of Moju, Pará State, Brazil, $\left(02^{\circ} 07^{\prime} 00^{\prime \prime} \mathrm{S}\right.$ and $\left.48^{\circ} \mathrm{W}\right)$. The soil is Yellow Oxisol with sandy to sandy-loam texture and with low chemical fertility (Table 1). The climate of the municipality in the Ami type (Köppen classification), characterized as tropical rainy, without seasonal variations, and average total rainfall of 2,500 $\mathrm{mm}$ annually. We also recorded annual rainfall and minimum and maximum temperatures (from 21 to 33 ${ }^{\circ} \mathrm{C}$ ) in the site during the experimental period (Figure 1). The average relative air humidity is $82 \%$ and constant annual solar illumination of $2,200 \mathrm{~h}$ of sunshine.

Table 1. Chemical characterization and clay concentration of the soil $(0-20 \mathrm{~cm})$ of the site before the experiment installation.

\begin{tabular}{cccccccc}
\hline $\mathbf{p H}$ & $\mathbf{S O C}$ & $\mathbf{C a}^{+2}$ & $\mathbf{M g}^{+2}$ & $\mathbf{P}$ & $\mathbf{K}^{+}$ & $\mathbf{V}$ & $\mathbf{C l a y}$ \\
\hline$\left(\mathrm{H}_{2} \mathrm{O}\right)$ & $\mathrm{g} \mathrm{kg}^{-1}$ & $--\mathrm{cmol}_{\mathrm{c}}$ & $\mathrm{dm}^{3}--$ & $\mathrm{mg}$ & $\mathrm{dm}^{-3}$ & $----\% \%^{---}$ & ------ \\
\hline 4.4 & 10.4 & 0.12 & 0.07 & 8 & 16 & 21 & 16 \\
\hline
\end{tabular}

SOC- Soil Organic Carbon (colorimetric method). $\mathrm{Ca}^{+2}, \mathrm{Mg}^{+2}$ and $\mathrm{K}^{+}$ extracted by ion exchange resin. P(Olsen method). V- Base saturation. 


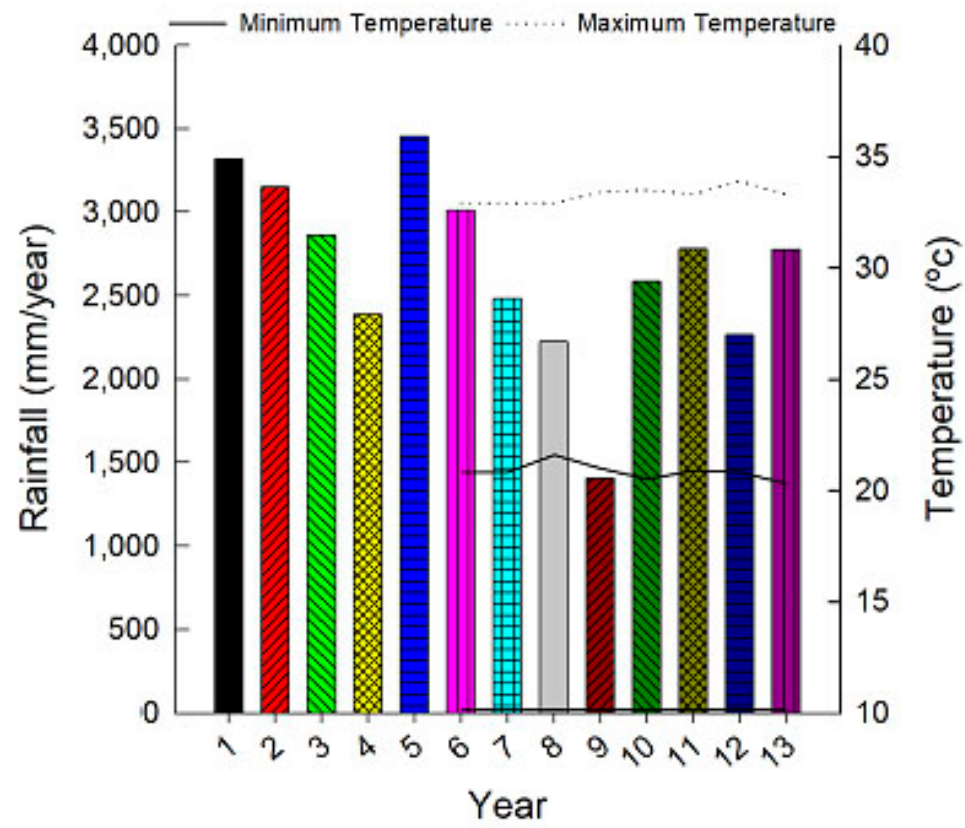

Figure 1. Annual rainfall and minimum and maximum temperatures in the site during the experimental period.

In the second semester of the year, site preparation included mechanized deforestation, burning, and swathing. In December of the same year, cover plant Pueraria phaseoloides was cultivated, sowing $10 \mathrm{~kg}$ of seeds/ha, as recommended by Lins and Viegas (2020). In March of the following year, coconut trees were planted at spacing $8.5 \times 8.5 \mathrm{~m}$ in the hexagonal system (7.4 $\mathrm{m}$ between rows), 160 plants/ha, covering an area of 9.45 ha. The cultivar used was hybrid PB - 121, a cross between yellow dwarf varieties from Malaysia and giant from western Africa. We carried out usual cultural treatments, necessary for the good development of coconut trees, such as cleaning pruning, crowning, and recess, among others.
Each experimental plot consisted of seven rows with eight plants each, excluding external rows from the evaluations. The statistical design was randomized blocks, with three replications and the treatments consisted of two levels of $\mathrm{N}\left(\mathrm{N}_{0}\right.$ and $\left.\mathrm{N}_{1}\right)$, three levels of $\mathrm{P}\left(\mathrm{P}_{0}, \mathrm{P}_{1}\right.$, and $\left.\mathrm{P}_{2}\right)$, three levels of $\mathrm{K}\left(\mathrm{K}_{0}, \mathrm{~K}_{1}\right.$, and $\left.\mathrm{K}_{2}\right)$, and three levels of $\mathrm{Mg}\left(\mathrm{Mg}_{0}, \mathrm{Mg}_{1}\right.$, and $\left.\mathrm{Mg}_{2}\right)$ (Table 2).

Table 2. Levels of nutrients applied in the treatments according to plant ages

\begin{tabular}{|c|c|c|c|c|c|c|c|c|c|c|c|}
\hline & $\mathbf{N}_{0}$ & $\mathbf{N}_{1}$ & $\mathbf{P}_{0}$ & $\mathbf{P}_{1}$ & $\mathbf{P}_{2}$ & $\mathbf{K}_{0}$ & $\mathbf{K}_{1}$ & $\mathbf{K}_{2}$ & $\mathbf{M g}_{0}$ & $\mathbf{M g}_{1}$ & $\mathbf{M g}_{2}$ \\
\hline Age & \multicolumn{2}{|c|}{------N----- } & \multirow{2}{*}{\multicolumn{3}{|c|}{$-\mathbf{-}_{2} \mathrm{O}_{5}$}} & \multicolumn{3}{|c|}{-------K2O----- } & \multicolumn{3}{|c|}{------------MgO------ } \\
\hline Years & & & & & & ha/y & & & & & \\
\hline & 0 & 14 & $13 *$ & $26 *$ & $30 *$ & 26 & 53 & 106 & 14 & & 48 \\
\hline 1 & 0 & $\begin{array}{l}14 \\
36\end{array}$ & $\begin{array}{r}0 \\
12\end{array}$ & $\begin{array}{c}20 \\
28\end{array}$ & $69^{\circ}$ & 0 & 62 & 125 & 0 & 28 & 48 \\
\hline 2 & 0 & $\begin{array}{l}36 \\
50\end{array}$ & 0 & 28 & 62 & 0 & 19 & 38 & 0 & 20 & 40 \\
\hline 3 & 0 & 58 & 0 & 11 & 22 & 0 & 77 & 154 & 0 & 13 & 26 \\
\hline 4 & 0 & 72 & 0 & 36 & 72 & 0 & 96 & 192 & 0 & 44 & 88 \\
\hline 5 & 0 & 72 & 0 & 36 & 72 & 0 & 96 & 192 & 0 & 44 & 88 \\
\hline 6 & 0 & 72 & 0 & 54 & 108 & 0 & 96 & 192 & 0 & 44 & 88 \\
\hline 7 & 0 & 72 & 0 & 54 & 108 & 0 & 96 & 102 & 0 & 44 & 88 \\
\hline 8 & 0 & 72 & 0 & 54 & 108 & 0 & 06 & 192 & 0 & 44 & 88 \\
\hline 9 & 0 & 72 & 0 & 43 & 86 & 0 & 70 & 192 & 0 & 35 & 70 \\
\hline 10 & 0 & 72 & 0 & 43 & 86 & 0 & 11 & 154 & 0 & 35 & 70 \\
\hline 11 & 0 & 72 & 0 & 43 & 86 & 0 & 77 & 154 & 0 & 22 & 44 \\
\hline 12 & 0 & 72 & 0 & 54 & 108 & 0 & 96 & 192 & 0 & 44 & 88 \\
\hline 13 & 0 & 72 & 0 & 54 & 108 & 0 & 96 & 192 & 0 & 44 & $\begin{array}{l}00 \\
88\end{array}$ \\
\hline 14 & 0 & 72 & 0 & 54 & 108 & 0 & 96 & 192 & 0 & 44 & 88 \\
\hline
\end{tabular}

*In this year, the simple superphosphate $\left(18 \% \mathrm{P}_{2} \mathrm{O}_{5}\right)$ was used as $\mathrm{P}$ source. 
Urea $(45 \% \mathrm{~N})$ was used as $\mathrm{N}$ source, simple superphosphate (only in the first year; $18 \% \mathrm{P}_{2} \mathrm{O}_{5}+18 \%$ $\mathrm{Ca}+10 \% \mathrm{~S}$ ) and triple superphosphate- TSP (in the other years; $45 \% \mathrm{P}_{2} \mathrm{O}_{5}+14 \% \mathrm{Ca}$ ) as $\mathrm{P}$ source, $\mathrm{KCl}$ as $\mathrm{K}$ source $\left(60 \% \mathrm{~K}_{2} \mathrm{O}\right)$, and $\mathrm{Mg}$ oxide as $\mathrm{Mg}$ source $(55 \%$ $\mathrm{MgO})$. The levels were initially defined according to the soil analysis and then according to plant ages, based on the leaf diagnosis. The fertilizer levels in the first two years of cultivation were divided into two applications (middle and end of year) and the levels were applied only once in the middle of the year, in the other years. The applications were carried out uniformly in the projection area of the leaf crown, within a 2-m radius from the stipe base. Before deploying the treatments, the experimental site was uniformly fertilized with 300 $\mathrm{kg} \mathrm{ha}^{-1}$ of natural phosphate (Gafsa; $28 \% \mathrm{P}_{2} \mathrm{O}_{5}$ ), due to the natural $\mathrm{P}$ deficiency of the soil (Table 1).

The response to nutrient fertilization was evaluated in terms of the concentration of macronutrients $(\mathrm{N}, \mathrm{P}, \mathrm{K}, \mathrm{Ca}, \mathrm{Mg}$, and $\mathrm{S})$ and micronutrients $(\mathrm{B}$ and $\mathrm{Cl})$ at the average coconut tree leaves. At the beginning of the rainy season in the region (December), samples of leaflets to determine the concentration of nutrients in the leaf were collected annually during eight years $\left(4^{\text {th }}\right.$ and $5^{\text {th }}$ and from the $8^{\text {th }}$ to the $13^{\text {th }}$ year of plant age), following the recommendations of IRHO (Institut de Recherches pour les Huiles et Oléagineux). In the first four years, leaf 9 was chosen to collect leaflets. From the fifth year onward, when the palms had more than 25 leaves, leaflets of leaf 14 were collected, according to the indications for the culture (LINS and VIEGAS, 2008). The foliar analyses were performed by the IRHO laboratory in France. The $\mathrm{N}$ was determined by the Kjedahl method; $\mathrm{P}$ by colorimetry using the ammonium vanadomolybdate method; $\mathrm{K}, \mathrm{Ca}$, and $\mathrm{Mg}$, by atomic absorption spectrophotometry; S was determined by atomic absorption spectrophotometry, indirect method, via barium; B was determined by the azomethine $\mathrm{H}$ method, and $\mathrm{Cl}$ was analyzed by titration with silver nitrate, according to the method indicated by IRHO (1980). In addition, in 10 years of harvest (from the $4^{\text {th }}$ to the $13^{\text {th }}$ year of plant age), production of coconut palms was evaluated in terms of the number of coconuts/plant/year, average fresh albumen weight (FAW/coconut) and FAW/ha/year. For the production variables, significant interactions are presented ( $\mathrm{P}$ and $\mathrm{K}$ levels, and $\mathrm{K}$ and $\mathrm{Mg}$ levels) on the average of the last three years of evaluation. The results were subjected to the analysis of variance $(p<0.05)$ and the means compared by the Tukey test using the SISVAR statistical program (FERREIRA, 2011).

\section{Results and Discussion}

In all the years studied, $\mathrm{N}$ concentration in the leaves of the coconut tree was not influenced by the fertilization of N, P, K, and Mg (Figure 2a). The supply of $\mathrm{N}(72 \mathrm{~kg} / \mathrm{ha} /$ year$)$ only increased leaf $\mathrm{N}$ concentration in two (9 and 10) of the eight years evaluated. In Rio Grande do Norte State (Brazil), for the three-yearold green dwarf coconut tree, leaf $\mathrm{N}$ concentrations increased linearly and proportionally to the amount of $\mathrm{N}$ applied (SILVA et al., 2009). However, in Ceará State (Brazil), higher N supply did not raise its levels in leaf 9 of green dwarf coconut tree in the fourth year in an Entisol (MATIAS et al., 2016). $\mathrm{N}$ application to the soil did not increase its leaf concentration in dwarf coconut, due to the competition between the anions $\left(\mathrm{Cl}^{-}\right.$and $\left.\mathrm{NO}_{3}^{-}\right)$for the absorption and transport sites in the plant (FERREIRA NETO et al., 2014).

For plants in production ( $>3$ years) with $\mathrm{N}$ leaf concentrations of $18-19 \mathrm{~g} \mathrm{~kg}^{-1}$, for 160 plants/ha, it is recommended to apply $\mathrm{N}$ at $72 \mathrm{~kg} / \mathrm{ha} /$ year (LINS and VIEGAS, 2020). Even in the absence of $\mathrm{N}$ fertilization $\left(\mathrm{N}_{0}\right), \mathrm{N}$ concentration was satisfactory and usually above the critical level (20.1 $\left.\mathrm{g} \mathrm{kg}^{-1}\right)$ established by DRIS for the nutrient in hybrid coconut in the region (SALDANHA et al., 2017). As recommended for the cultivation of coconut tree (LINS and VIEGAS, 2008), the use of legume Pueraria phaseoloides ensures a satisfactory $\mathrm{N}$ nutrition. Leguminous plants fix atmospheric $\mathrm{N}$ by association with bacteria of the genus Rhizobium, making it available for successive or intercropping crops, after senescence. The literature indicates a contribution of $\mathrm{P}$. phaseoloides as an $\mathrm{N}$ supplier of $455 \mathrm{~kg} / \mathrm{ha}$ in the second year (PEREZ, 1997), much higher than the largest $\mathrm{N}$ dose applied in our study (Table 2). For a production of 130 fruits/plant/year, 57 $\mathrm{kg} / \mathrm{ha}$ of $\mathrm{N}$ are exported (OUVRIER, 1990), well below the contribution of $\mathrm{P}$. phaseoloides. Lower $\mathrm{C} / \mathrm{N}$ ratio of the residue, higher rainfall, and high temperatures observed in the region (Figure 1) favor mineralization and consequent release of $\mathrm{N}$ fixed by the legume to the coconut crop.

Nitrogen fertilization increased leaf $\mathrm{P}$ concentration only in the fifth year of the coconut tree (Figure 2b). Despite a strong synergism between the $\mathrm{N}$ and $\mathrm{P}$ concentration in palm trees, $\mathrm{N}$ fertilization has a favorable effect on the $\mathrm{P}$ concentration in the plant (SILVA et al., 2009); however, this fact was not observed in our study. The leaf P concentration was only influenced by $\mathrm{K}$ fertilization in four years $(8,9$, 10 and 13) and by $\mathrm{Mg}$ fertilization in two years ( 9 and 13). A synergism between $\mathrm{Mg}$ and $\mathrm{P}$ is observed in which absorption of $\mathrm{Mg}$ is maximum in the presence of P. Magnesium acts on chloroplast phosphorylation, synthesis of the ATP molecule and is a substrate for ATPases in the plant (MALAVOLTA et al., 1997). 


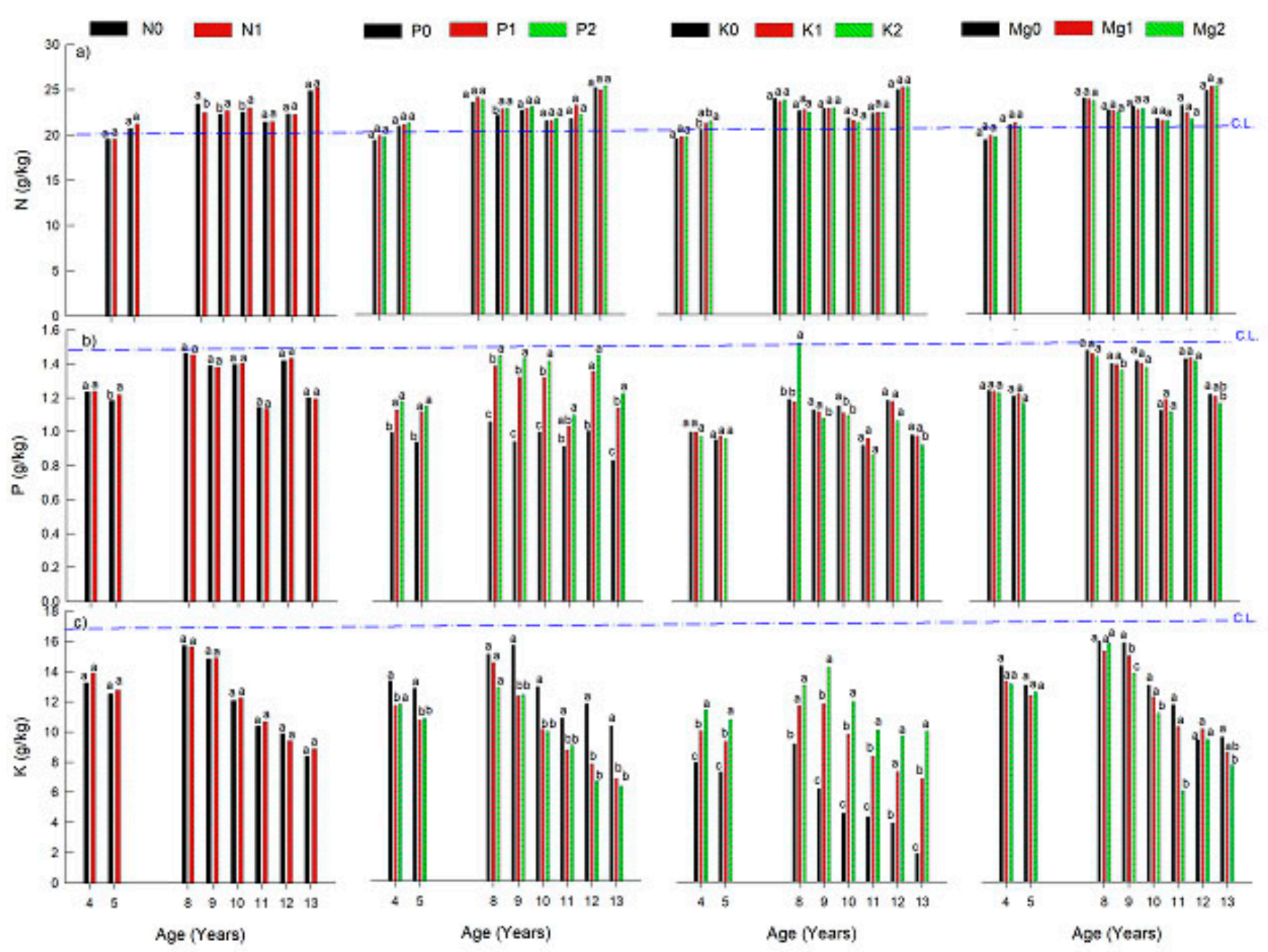

Figure 2. Leaf concentrations $(\mathrm{g} / \mathrm{kg})$ of $\mathrm{N}(\mathrm{a}), \mathrm{P}(\mathrm{b})$, and $\mathrm{K}(\mathrm{c})$ in coconut trees at different ages submitted to fertilization with nitrogen, phosphorus, potassium, and magnesium. Means followed by the same letters in the columns are considered statistically equal by the Tukey test ( $\mathrm{p}>0.05)$. C.L. - Critical Level established for the region of the present study with the DRIS method (SALDANHA et al., 2017).

On the other hand, $\mathrm{P}$ fertilization increased leaf $\mathrm{P}$ concentrations in all years studied, with no significant differences between the $\mathrm{P}_{1}$ and $\mathrm{P}_{2}$ levels in four years (Figure 2b). The average concentration of $1.4 \mathrm{~g} \mathrm{~kg}^{-1}$ in $\mathrm{P}_{1}$ coincides with the critical level proposed (LINS et al., 2003) and is close to the level established for the region (1.5 $\mathrm{g} \mathrm{kg}^{-1}$; SALDANHA et al., 2017), although such levels were not reached, in most cases (Figure 2b). According to Ferreira Neto et al. (2014), the coconut tree has little requirement for $\mathrm{P}$; nevertheless, $\mathrm{P}$ is important for its action in the regeneration of triphosphoric acid, abundant in young organs and in the energy transport related reactions.

Nitrogen fertilization did not influence leaf $\mathrm{K}$ concentrations, whereas $\mathrm{P}\left(\mathrm{P}_{1}\right.$ and $\left.\mathrm{P}_{2}\right)$ and $\mathrm{Mg}$ applications decreased their concentrations in most years evaluated (years 9, 10, 11 and 13) (Figure 2c). The effect of $\mathrm{P}$ fertilization on the reduction of leaf $\mathrm{K}$ concentrations must be related to the presence of $\mathrm{Ca}$ in $\mathrm{P}$ source (TSP; $18 \% \mathrm{CaO}$ ), since the increase in $\mathrm{Ca}$ supply can decrease $\mathrm{K}$ absorption by antagonism
(MALAVOLTA et al., 1997). Interactions occur in mineral nutrition of the coconut tree, such as antagonism between $\mathrm{K}$ and $\mathrm{Ca}$ and between $\mathrm{K}$ and $\mathrm{Mg}$, which is more significant (LINS and VIEGAS, 2008).

On the other hand, in all years studied, $\mathrm{K}$ fertilization increased leaf $\mathrm{K}$ concentrations of coconut trees, although below the critical level of $17.2 \mathrm{~g} \mathrm{~kg}^{-1}$ established for hybrid coconut plants in the region (SALDANHA et al., 2017). In the absence of $\mathrm{KCl}$ $\left(\mathrm{K}_{0}\right)$, leaf $\mathrm{K}$ concentration was very low (average of $7.8 \mathrm{~g} \mathrm{~kg}^{-1}$ ), with an average value almost doubled in $\mathrm{K}_{1}$, reaching $15.8 \mathrm{~g} \mathrm{~kg}^{-1}$ in $\mathrm{K}_{2}$. Over the years, leaf $\mathrm{K}$ concentration in the absence of $\mathrm{KCl}$ decreased, due to the depressive effects of TSP and $\mathrm{MgO}$ on $\mathrm{K}$ nutrition, mainly in the absence of $\mathrm{P}$ fertilization (Figure 2c). In green dwarf coconut palm, $\mathrm{K}$ concentrations also increased in the leaves (SILVA et al., 2009; RIBEIRO et al., 2016) and in the water and in fruit peel, due to $\mathrm{K}$ fertilization (RIBEIRO et al., 2011). In Rio Grande do Norte State, leaf K concentrations showed a high correlation with the number of fruits in the sixth year 
of cultivation of green dwarf coconut tree (FERREIRA NETO et al., 2014). Silva et al. (2009) suggest a high extraction power of $\mathrm{K}$ by the coconut tree, although the literature reports varied values. For Lins (2000), $\mathrm{K}$ has the largest withdrawal in the coconut crop (193 $\mathrm{kg} / \mathrm{ha}$ ) and, for a production of 130 fruits/plant/year, Ouvrier (1990) reported an export of $110 \mathrm{~kg} / \mathrm{ha}$ of $\mathrm{K}_{2} \mathrm{O}$. However, values of $\mathrm{K}$ accumulation by the coconut tree can reach $248 \mathrm{~kg} / \mathrm{ha}$ with $78 \%$ of this accumulation removed by the fruits (MAGAT, 2005), indicating the need for replacement by fertilization, especially in soils with low K availability (Table 1).
Leaf $\mathrm{Ca}$ concentrations were not influenced by $\mathrm{N}$ fertilization (Figure 3a), although there are reports of a significant increase in Ca concentrations due to $\mathrm{N}$ fertilization (LINS and VIEGAS, 2008). P fertilization increased $\mathrm{Ca}$ concentrations in coconut plants (Figure 3a), similar to reports in the literature (LINS and VIEGAS, 2008), due to the presence of $\mathrm{Ca}$ in the TSP composition. In the absence of P fertilization, $\mathrm{Ca}$ nutrition is deficient (Figure 3a). The supply of $54 \mathrm{~kg} / \mathrm{ha} /$ year de $\mathrm{P}_{2} \mathrm{O}_{5}\left(\mathrm{P}_{1}\right)$ raised the average leaf Ca concentrations to $4.3 \mathrm{~g} \mathrm{~kg}^{-1}$, above the critical level $4.1 \mathrm{~g} \mathrm{~kg}^{-1}$ established for $\mathrm{Ca}$ under the edaphoclimatic conditions of Moju, Pará State (SALDANHA et al., 2017). For Lins (2000), Ca leaf concentrations between 3 and $4 \mathrm{~g} \mathrm{~kg}^{-1}$ are satisfactory and the application of $\mathrm{Ca}$ fertilizers does not mean yield increase. Experiments with PB-121 hybrid from the Ivory Coast shows that P fertilization increased leaf $\mathrm{Ca}$ concentrations by $23.5 \%$ in four years (IRHO, 1989).

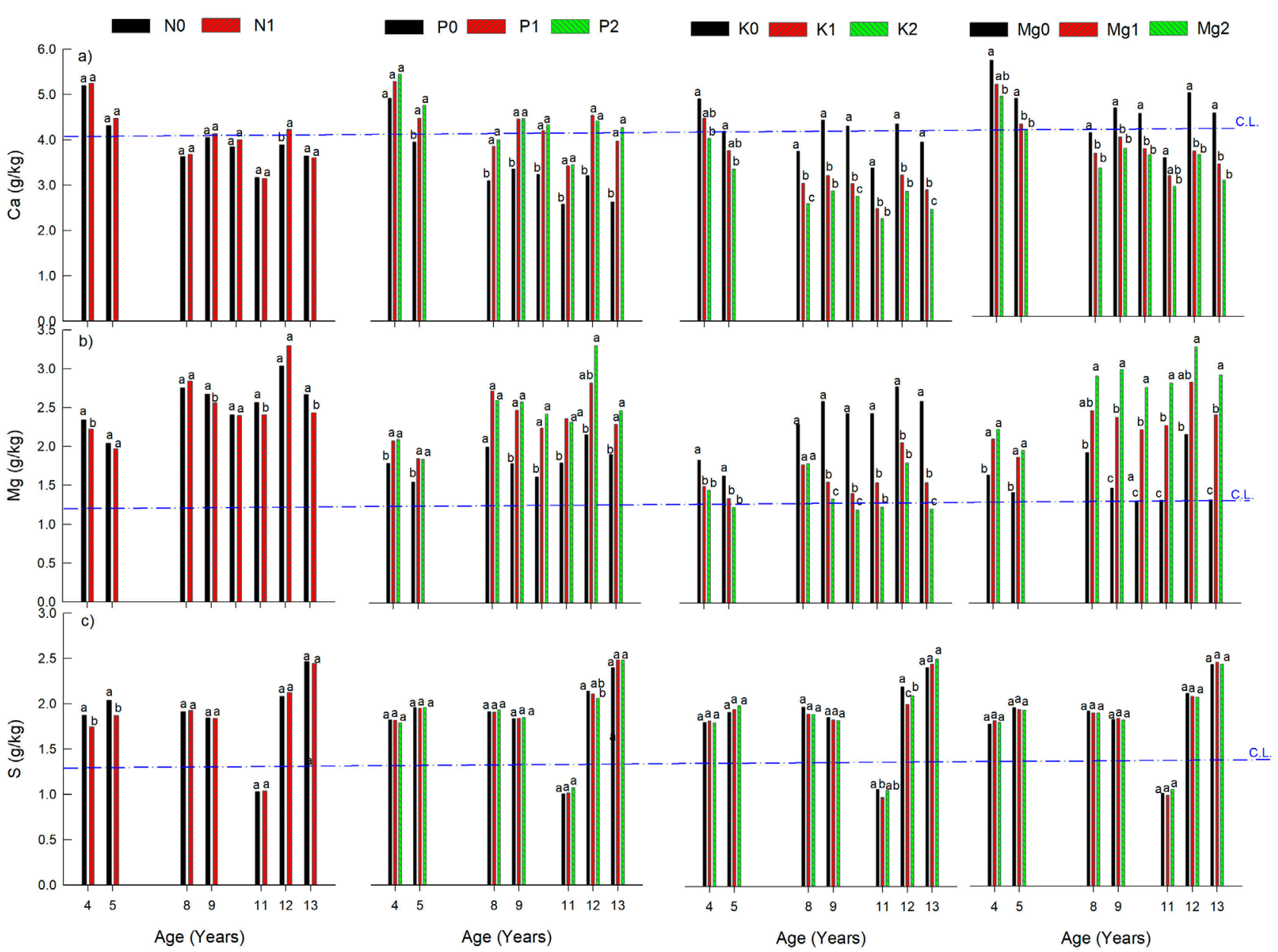

Figure 3. Leaf concentrations ( $\mathrm{g} / \mathrm{kg}$ ) of $\mathrm{Ca}(\mathrm{a}), \mathrm{Mg}(\mathrm{b})$, and $\mathrm{S}(\mathrm{c})$ in coconut trees at different ages submitted to fertilization with nitrogen, phosphorus, potassium, and magnesium. Means followed by the same letters in the columns are considered statistically equal by the Tukey test $(p>0.05)$. C.L. - Critical Level established for the region of the present study with the DRIS method (SALDANHA et al., 2017). 
Conversely, $\mathrm{K}$ and $\mathrm{Mg}$ fertilization decreased leaf $\mathrm{Ca}$ concentrations (Figure 3a), due to the antagonism of competitive inhibition between the nutrients (MALAVOLTA et al., 1997) also verified in coconut (LINS and VIEGAS, 2008). P fertilization decreased leaf $\mathrm{Ca}$ concentration in coconut by up to $53 \%$. In the absence of $\mathrm{K}$ application, Ca concentration was $4.5 \mathrm{~g}$ $\mathrm{kg}^{-1}$ (average of the last three years of evaluations). In $\mathrm{K}_{1}$, Ca concentration reduced to $3.3 \mathrm{~g} \mathrm{~kg}^{-1}$, while in $\mathrm{K}_{2}$ showed a decrease of $50 \%$ of $\mathrm{Ca}$ concentration in the leaves (Figure 3a). Ferreira Neto et al. (2014) report that, as $\mathrm{K}$ is monovalent and with a lower hydration degree, it has preferential absorption over bivalent cations, such as $\mathrm{Ca}$ and $\mathrm{Mg}$.

There was no consistency in the response of leaf $\mathrm{Mg}$ concentrations in relation to $\mathrm{N}$ fertilization in the years of evaluation, with a concentration decrease observed only in some years $(4,9,11$, and 13) (Figure 3b). Silva et al. (2009) observed a linear reduction in leaf $\mathrm{Mg}$ concentrations due to $\mathrm{N}$ fertilization in green dwarf coconut. Except for the eighth year, leaf $\mathrm{Mg}$ concentrations increased (up to 29\%) in all other years, due to $\mathrm{P}$ application. In addition, in all the years evaluated, $\mathrm{Mg}$ fertilization increased leaf $\mathrm{Mg}$ concentrations of coconut plants. Without the application of $\mathrm{MgO}$, the average leaf $\mathrm{Mg}$ concentration is $1.8 \mathrm{~g} \mathrm{~kg} \mathrm{~g}^{-1}$, while its leaf concentration in the presence of $\mathrm{Mg}_{1}$ increased to $2.7 \mathrm{~g} \mathrm{~kg}^{-1}$ of $\mathrm{Mg}$, rising to $3.1 \mathrm{~g} \mathrm{~kg}^{-1}$ of $\mathrm{Mg}$ in the presence of the second level of $\mathrm{Mg}\left(\mathrm{Mg}_{2}\right)$. In most cases, leaf $\mathrm{Mg}$ concentration was way above the critical level $1.2 \mathrm{~g} \mathrm{~kg}^{-1}$ established for the culture in the region (SALDANHA et al., 2017). Conversely, except for the eighth year, $\mathrm{KCl}$ fertilization decreased leaf $\mathrm{Mg}$ concentration of coconut trees (Figure $3 \mathrm{~b}$ ) by up to $45 \%$, again due to the antagonism between $\mathrm{K}$ and $\mathrm{Mg}$ already observed for the crop (LINS and VIEGAS, 2008). In the Brazilian Northeast, $\mathrm{KCl}$ fertilization also decreased leaf $\mathrm{Mg}$ concentration of five-year-old (RIBEIRO et al., 2016) and three-year-old (SILVA et al., 2009) green dwarf coconut trees.

In most years evaluated, leaf $\mathrm{S}$ concentrations were not influenced by $\mathrm{N}, \mathrm{P}, \mathrm{K}$, and $\mathrm{Mg}$ fertilizations and were always above (Figure 3c) the critical level $1.3 \mathrm{~g} \mathrm{~kg}^{-1}$ reported for the region of the present study (SALDANHA et al., 2017), except for year 11.

In most cases, there was no significant effect of $\mathrm{N}, \mathrm{P}$, and $\mathrm{Mg}$ fertilizations on leaf $\mathrm{B}$ concentrations up to the 13 years of age of the plants. However, K fertilization decreased leaf $\mathrm{B}$ concentrations of coconut trees in most years evaluated (Figure 4a). In eight years of evaluation, $\mathrm{KCl}$ fertilization $\left(\mathrm{K}_{2}\right)$ reduced leaf $\mathrm{B}$ concentration by $25 \%$ on average. Applications of high $\mathrm{KCl}$ levels decreased leaf $\mathrm{B}$ concentrations by $4.6 \mathrm{mg} \mathrm{kg}^{-1}$, which becomes a limiting factor in the absence of B-based fertilizers. Therefore, there is possibly an antagonism in the absorption between chloride (present in $\mathrm{KCl}$ ) and boric acid or borate in coconut palms. Compared to $\mathrm{Cl}^{-}$or $\mathrm{NO}_{3}^{-}, \mathrm{B}$ is more adsorbed to soil components (ABREU et al., 2007). However, high $\mathrm{Cl}^{-}$concentrations in the soil solution due to higher $\mathrm{KCl}$ levels may have caused greater $\mathrm{B}$ desorption from the colloids with consequent greater leaching of this micronutrient, intensified by the high rainfall levels in the region (Figure 1), contributing to less absorption of B by plants (Figure 4a). According to the International Plant Problem Insights (1989), as oil palm is a large $\mathrm{KCl}$ consumer, high rates of $\mathrm{K}$ fertilizer induce B deficiency; therefore, the application of both fertilizers is recommended, mainly in tropical acidic soils, poor in organic matter $(\mathrm{OM})$, main $B$ source in the soil (ABREU et al., 2007).

Except for years 11 and 12, leaf B concentrations were lower than the critical levels of $20 \mathrm{mg} \mathrm{kg}^{-1}$ (LINS et al., 2003) or $15 \mathrm{mg} \mathrm{kg}^{-1}$ (SALDANHA et al., 2017) established for the hybrid coconut tree in the region, indicating its deficiency. Low B absorption by plants in the present study (Figure 4a) may be attributed to lower $\mathrm{OM}$ concentration in the soil, low clay concentration, acidic $\mathrm{pH}$, and high rainfall (DECHEN et al., 2018), besides the absence of $\mathrm{B}$ fertilization (Table 1; Figure 1). Intense rains in tropical conditions, especially in sandy soils, increase B losses by leaching, decreasing its availability and absorption (ABREU et al., 2007). Leaves sampled four months after the first B application to the soil in a five-year-old green dwarf coconut tree showed an average B concentration of $40 \mathrm{mg} \mathrm{kg}^{-1}$ (PINHO et al., 2008), well above the levels verified in the present study (Figure 4a). These authors verified $B$ redistribution in coconut plants, regardless of the application mode, a relevant fact since B is known to be immobile (DECHEN et al., 2018). Research indicates that $\mathrm{B}$ can be mobile in certain plants because they produce simple sugars, polyols, which bind with $\mathrm{B}$ and form the sugar-B complex, promoting its mobility (BROWN and HU, 1998).

In most years evaluated, leaf $\mathrm{Cl}$ concentrations were significantly influenced only by $\mathrm{K}$ fertilization with an increase up to five fold (Figure $4 \mathrm{~b}$ ). In the eighth year, $\mathrm{K}_{1}\left(96 \mathrm{~kg} / \mathrm{ha}\right.$ of $\left.\mathrm{K}_{2} \mathrm{O}\right)$ increased leaf $\mathrm{Cl}$ concentration by $90 \%$ and by $109 \%$ with $\mathrm{K}_{2}\left(192 \mathrm{~kg} / \mathrm{ha}\right.$ of $\left.\mathrm{K}_{2} \mathrm{O}\right) . \mathrm{KCl}$ application increased leaf $\mathrm{Cl}$ concentration of coconut tree in Rio Grande do Norte State (SILVA et al., 2009; FERREIRA NETO et al., 2014) and in Rio de Janeiro State (RIBEIRO et al., 2016). Adequate $\mathrm{Cl}$ supply to the coconut tree is important due to the crop requirement and $\mathrm{Cl}$ supply may deficient mainly in crops far from the coast (SOBRAL, 2003). The estimate of $\mathrm{Cl}$ extraction by the coconut tree is $125 \mathrm{~kg} / \mathrm{ha}$, which makes it the second most exported nutrient, even higher than $\mathrm{N}$ (LINS, 2000). With the exception of year 11 and 12, in most other cases, leaf $\mathrm{Cl}$ concentration was below (Figure $4 \mathrm{~b})$ the critical level $\left(5.0 \mathrm{~g} \mathrm{~kg}^{-1}\right)$ established by Magat (1991), despite $\mathrm{KCl}$ applications (Table 2). 


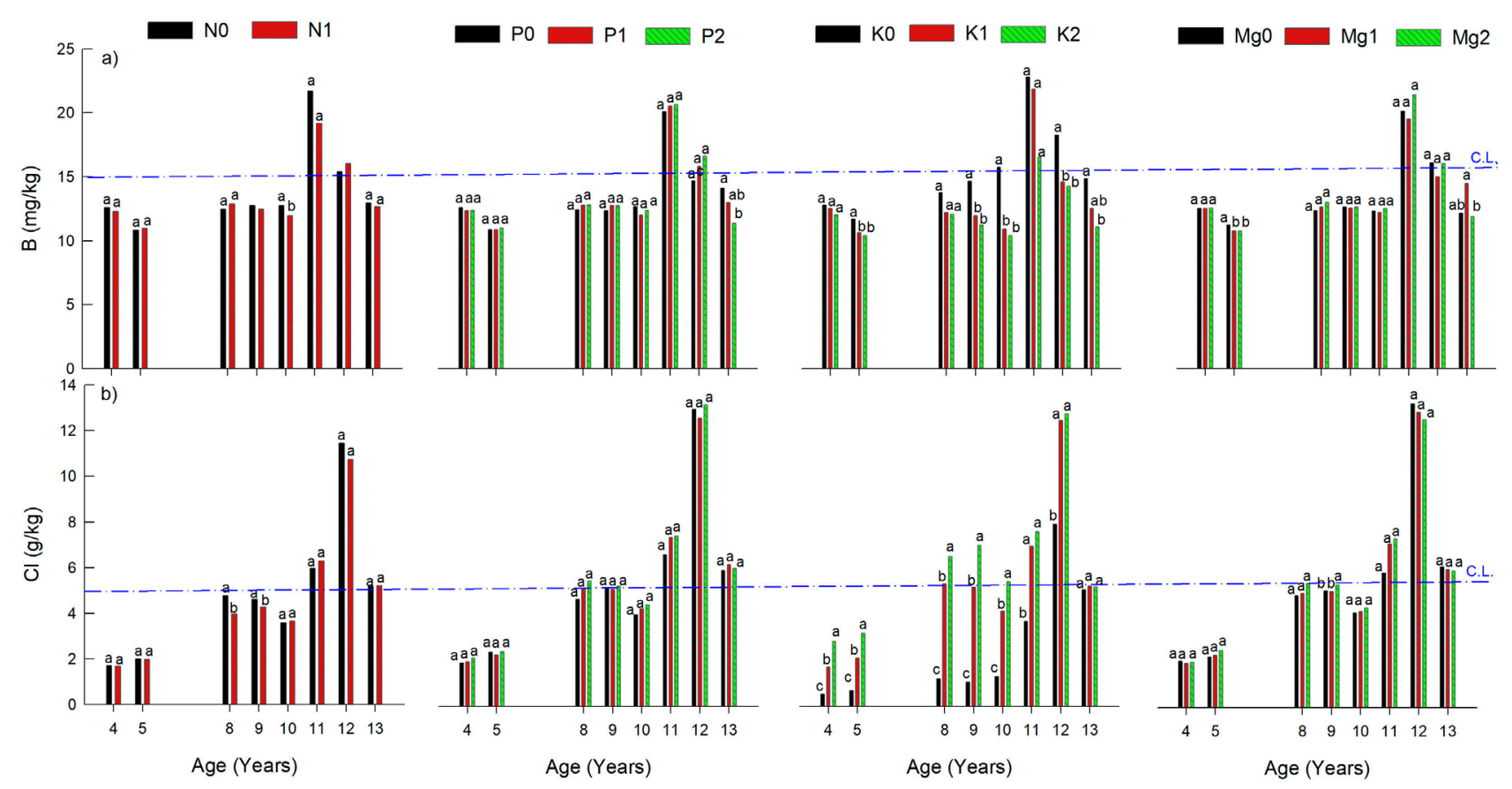

Figure 4. Leaf concentrations of $\mathrm{B}(\mathrm{a})$, in $\mathrm{mg} / \mathrm{kg}$, and $\mathrm{Cl}(\mathrm{b})$, in $\mathrm{g} / \mathrm{kg}$ in coconut trees at different ages submitted to fertilization with nitrogen, phosphorus, potassium, and magnesium. Means followed by the same letters in the columns are considered statistically equal by the Tukey test ( $p>0.05)$. C.L. - Critical Level of B by the DRIS method (SALDANHA et al., 2017) and of Cl (MAGAT, 1991) established for the region of the present study.

Assessment in 10 years of production (from the $4^{\text {th }}$ to the $13^{\text {th }}$ year of plant age), the number of coconuts/plant, FAW/coconut and FAW/ha/year were not influenced by $\mathrm{N}$ fertilization in the form of urea (Figures $5 \mathrm{a}, 5 \mathrm{~b}$, and $5 c)$. Soil cover with legume Pueraria phaseoloides, sown before the implantation of the coconut crop, ensured soil protection and $\mathrm{N}$ supply to the plants (Figure 2a), in soil with medium concentration of OM (Table 1) and high rainfall indexes of the region (Figure 1). Soil OM is the main $\mathrm{N}$ source for plants in the soil, accounting for up to $95 \%$ of total $\mathrm{N}$ in the soil (SILVA and MENDONÇA, 2007). Furthermore, $N$ applied as urea to the soil surface can promote significant $\mathrm{N}$ losses due to ammonia volatilization (CANTARELLA, 2007) and reduce crop response to its application (Figure 5a).

Lack of response to $\mathrm{N}$ application in coconut production has also been recorded in several experiments in West Africa and in Indonesia (OLLAGNIER and WAHYUNI, 1984). In São Paulo State (Brazil), N fertilization had a negative effect on water volume, average fruit mass, and on the number of fruits/bunch of dwarf coconut trees (TEIXEIRA et al., 2005a). On the other hand, in the Brazilian Northeast, coconut trees showed response to N fertilization (SOBRAL, 2004; SILVA et al., 2006). These results differ from our findings, due to different edaphoclimatic conditions, management practices, and age of plants. Regarding genotypic differences, Lins (2000) reported a great similarity in the extraction of nutrients, considering the same yield, between the hybrid and the giant coconut cultivars.
In all the years evaluated, $P$ fertilization increased the number of coconuts/plant (Figure 5a) and FAW/ ha (except for years 5 and 12) (Figure 5c); however, $P$ addition reduced FAW/coconut by $6 \%$ from in 9 -yearold plants (Figure 5b). Coconut plants fertilized with $P$ yielded, on average, 66.2 coconuts/plant/year $\left(\mathrm{P}_{1}\right)$ and 67.6 coconuts/plant/year $\left(\mathrm{P}_{2}\right)$. In the absence of $\mathrm{P}$ application $\left(\mathrm{P}_{0}\right)$, production was only 52.7 coconuts/ plant/year, on average, 30\% less than the plants under $\mathrm{P}$ fertilization. The production of treatments $\mathrm{P}_{1}$ and $\mathrm{P}_{2}$ showed no significant differences between each other. During 10 years of evaluations, average yield of $P_{1}$ was 76.2 coconuts/plant/year, while $P_{2}$ reached 78.1 coconuts/plant/year (Figure 5).

Regarding coconut quality, assessed by means of FAW/coconut, $\mathrm{P}$ applications in the form of TSP did not influence fruit quality in the first five years of evaluations. However, P supply subsequently decreased fruit weight (Figure 5b). In five consecutive years, FAW/ coconut was reduced by $6.3 \%$ in $\mathrm{P}_{1}$ treatment and by $5.4 \%$ in $\mathrm{P}_{2}$ treatment. In eight of the ten years evaluated, $\mathrm{P}$ application significantly increased FAW/ha (Figure $5 \mathrm{c})$. The average yield in the last three years $(11,12$, and 13) of $\mathrm{P}_{0}$ treatment was $3.52 \mathrm{t} / \mathrm{ha}$ of FAW, whereas $\mathrm{P}_{1}\left(54 \mathrm{~kg} / \mathrm{ha} /\right.$ year of $\left.\mathrm{P}_{2} \mathrm{O}_{5}\right)$ had an increase of $1.20 \mathrm{t} / \mathrm{ha}$ of FAW, a $33.9 \%$ gain, production statistically similar to that obtained in $\mathrm{P}_{2}\left(108 \mathrm{~kg} / \mathrm{ha} /\right.$ year of $\left.\mathrm{P}_{2} \mathrm{O}_{5}\right)$ (Figures 6a). Thus, for economic reasons, the lowest $\mathrm{P}$ dose (54 $\mathrm{kg} / \mathrm{ha} /$ year of $\mathrm{P}_{2} \mathrm{O}_{5}$ ) is recommended for the coconut crop in the region evaluated. In Pará State, there is a recommendation of $72 \mathrm{~kg} / \mathrm{ha} /$ year of $\mathrm{P}_{2} \mathrm{O}_{5}$ for coconut 
palm in production ( $>3$ years, 160 plants/ha) with leaf $\mathrm{P}$ concentration between 1.1 and $1.2 \mathrm{~g} \mathrm{~kg}^{-1}$ (LINS and VIEGAS, 2020). The lowest $\mathrm{P}$ dose of fertilization recommended in the present study indicates a specific recommendation for the coconut crop under the edaphoclimatic conditions of the municipality of Moju, compared to the recommendation for the state of Pará (LINS and VIEGAS, 2020). In São Paulo State, 120 $\mathrm{kg} / \mathrm{ha}$ of $\mathrm{P}_{2} \mathrm{O}_{5}\left(\mathrm{P}\right.$ resin $\left.<13 \mathrm{mg} / \mathrm{dm}^{3}\right)$ are recommended for an expected yield above $30 \mathrm{t} / \mathrm{ha}$ (TEIXEIRA et al., 2005b).

The positive response to $\mathrm{P}$ fertilization in plant production due to the low natural fertility of the cultivated soil (Table 1), which provided leaf concentrations below P critical level, despite fertilizations (Figures 2b) and the fact that the coconut crop is considered unresponsive $\mathrm{P}$ fertilization
(KHAN et al., 1985). P fertilization increased leaf $\mathrm{P}$ concentration; nevertheless, the P critical level was only reached in the 12-year-old plants, in the last three years evaluated (Figure 6a). This fact indicates a greater potential of crop response to $\mathrm{P}$ application at levels higher than the maximum level evaluated in this study $\left(108 \mathrm{~kg} / \mathrm{ha} /\right.$ year of $\left.\mathrm{P}_{2} \mathrm{O}_{5}\right)$. In addition, in weathered tropical soils, $\mathrm{P}$ has low natural availability due to its high adsorption to $\mathrm{Fe}$ and $\mathrm{Al}$ oxides and precipitation with Al ions in solution (NOVAIS et al., 2007) thus increasing the potential of crop response. Unlike the results obtained in the current study, $\mathrm{P}$ application did not influence fruit production of the dwarf coconut tree planted in São Paulo State (TEIXEIRA et al., 2005a). Phosphorus is ranked seventh in order of nutritional importance for the coconut tree (OUVRIER, 1990).
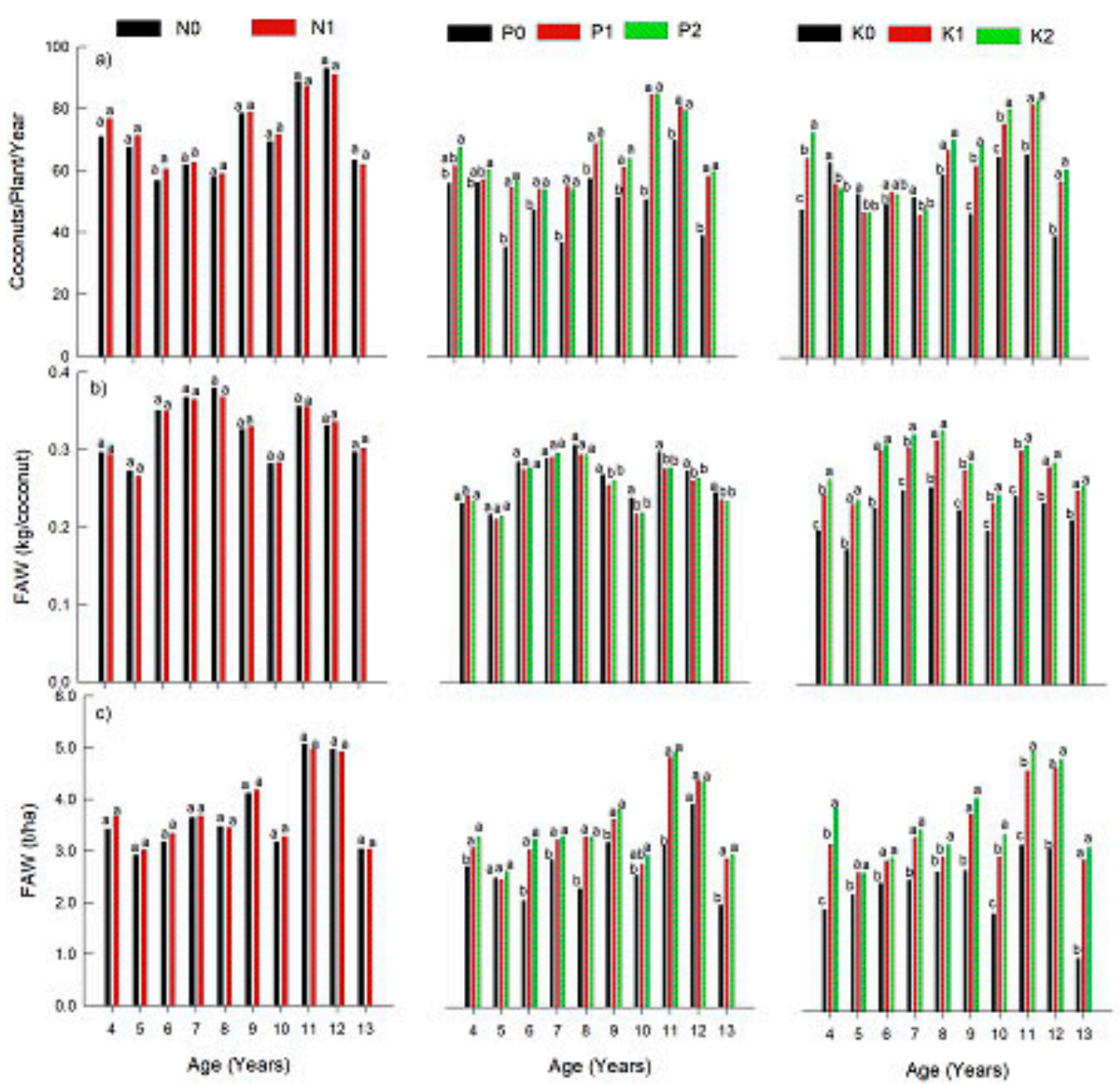
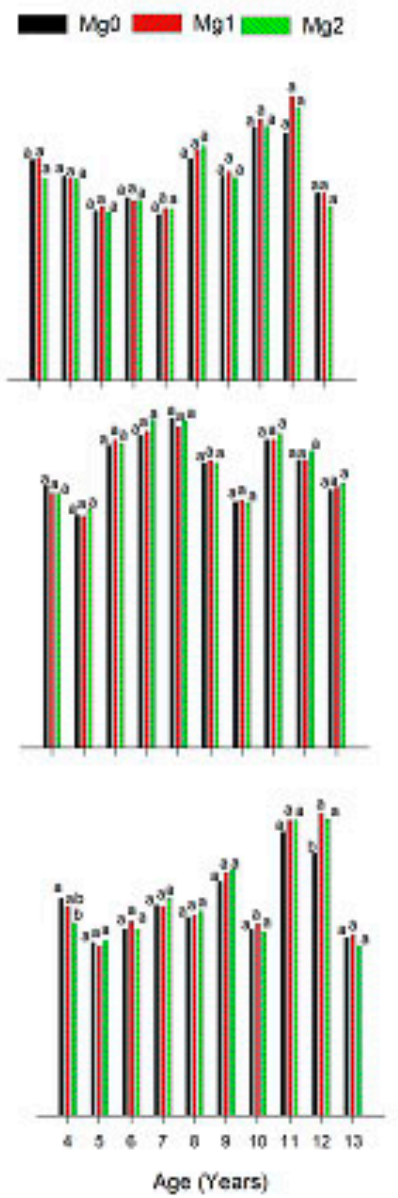

Figure 5. Production of coconuts/plant/year (a), fresh albumen weight-FAW/coconut (b) and FAW/ha/year (c) of coconut trees at different ages submitted to nitrogen, phosphorus, potassium, and magnesium fertilization. Means followed by the same letters in the columns are considered statistically equal by the Tukey test ( $\mathrm{p}>0.05)$. 

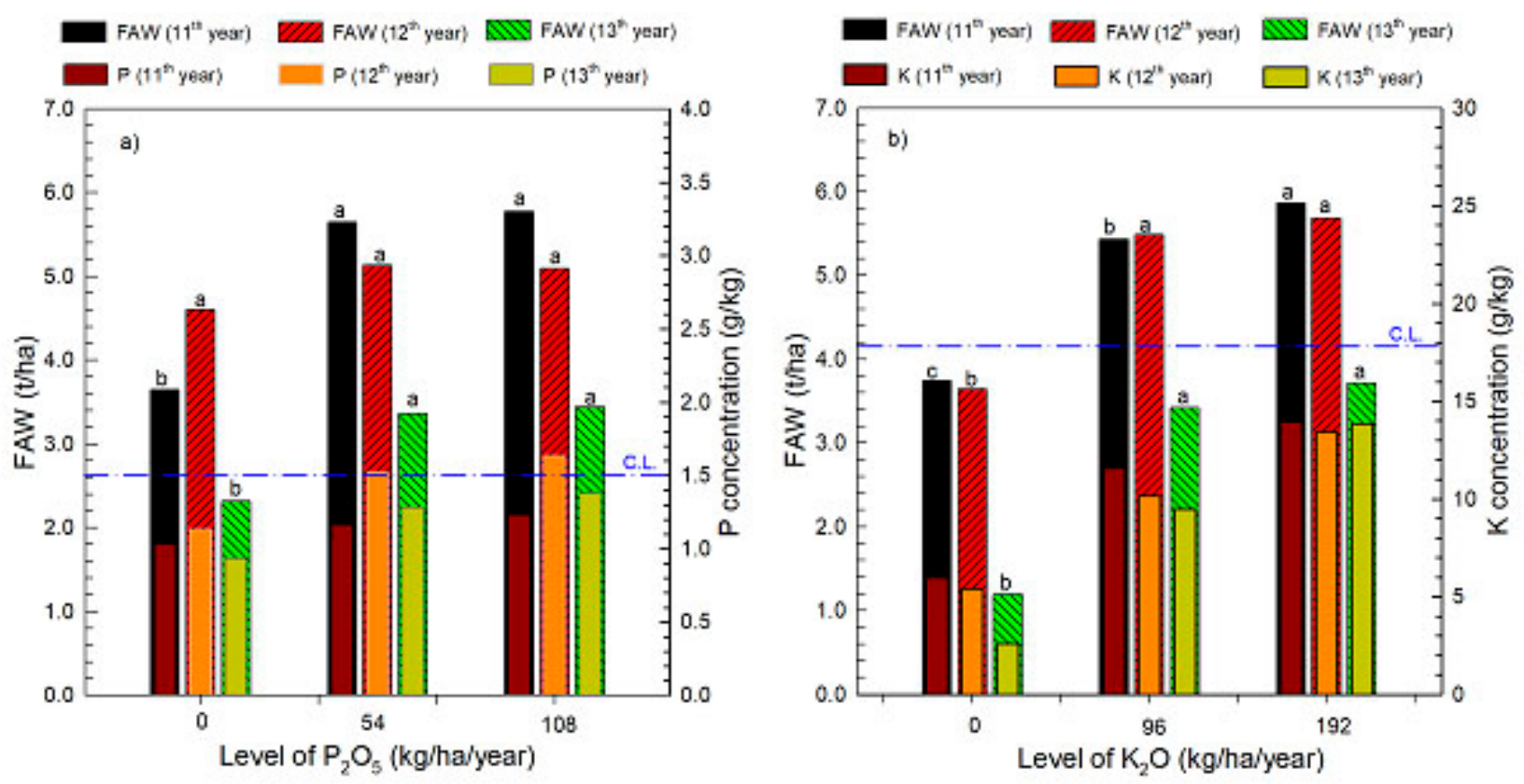

Figure 6. Production of fresh albumen weight-FAW/ha and leaf $\mathrm{P}$ concentration in coconut trees $(11,12$, and 13 years old) submitted to phosphorus fertilization (a) and FAW/ha and $\mathrm{K}$ leaf concentration in coconut trees $(11,12$, and 13 years old) submitted to potassium fertilization (b). Means, comparing FAW between the levels of each nutrient in each year followed by the same letters in the columns are considered statistically equal by the Tukey test ( $\mathrm{p}>0.05)$. C.L. - Critical Level established for the region of the present study with the DRIS method (SALDANHA et al., 2017).

Throughout the evaluation period, K fertilization had a positive effect on production variables, except for the number of coconuts/plant/year at five, six, and eight years of age (Figure 5). In the last three years evaluated (11-13), plants that received $96 \mathrm{~kg} / \mathrm{ha} /$ year of $\mathrm{K}_{2} \mathrm{O}$ had an average yield of 85.6 coconuts compared to 67.8 coconuts/plant produced in $\mathrm{K}_{0}$ (without $\mathrm{K}$ ), while with the application of $192 \mathrm{~kg} / \mathrm{ha}$ of $\mathrm{K}_{2} \mathrm{O}\left(\mathrm{K}_{2}\right)$ yielded 86.8 coconuts/plant, statistically equal to $\mathrm{K}_{1}$ (Figure 5a). In the Ivory Coast, $\mathrm{K}$ fertilization raised the yield of hybrid PB 121 from 52.3 to 99 coconuts/ plant/year and increased the albumen weight by $13.9 \%$ (MANCIOT et al., 1980). In the Brazilian Northeast, the green dwarf coconut tree responded to $\mathrm{K}$ fertilization and, in the seventh year, the yield was above 200 fruits/ plant for all levels applied (FERREIRA NETO et al., 2014), also indicating possible genotypic differences in production capacity compared to the hybrid used in the present study (Figure 5). According to Lins and Viegas (2008), the coconut crop potential can reach 80 to 200 fruits/plant/year.

The low natural fertility of the soil (Table 1) reflected in leaf $\mathrm{K}$ concentrations below its critical level, despite fertilizations (Figure 2c) and thus contributed to the positive response to $\mathrm{K}$ application in crop yield (Figure 5). Considering the last three years of evaluation $(11,12$, and 13$), \mathrm{K}$ fertilization provided greater FAW/ha; however, without difference between the applications of 96 and $192 \mathrm{~kg} / \mathrm{ha} /$ year of $\mathrm{K}_{2} \mathrm{O}$ (Figure 6b), thus, the level $96 \mathrm{~kg} / \mathrm{ha} /$ year of $\mathrm{K}_{2} \mathrm{O}$ is indicated. Although $\mathrm{K}$ application increased its leaf concentration, the critical K level was not reached (Figure 6b). This indicates that the levels tested were not sufficient to provide adequate $\mathrm{K}$ nutrition to coconut trees (Figure $6 b)$ and thus possibly limited their productive potential. Future studies should investigate higher K levels for the crop in the region. In the state of Pará, for 160 plants/ha, the recommendation is to apply $192 \mathrm{~kg} / \mathrm{ha} /$ year of $\mathrm{K}_{2} \mathrm{O}$ for coconut plants with leaf $\mathrm{K}$ concentrations between 11 and $12 \mathrm{~g} \mathrm{~kg}^{-1}$ (LINS and VIEGAS, 2020). In turn, in São Paulo State, it is recommended $300 \mathrm{~kg} / \mathrm{ha} /$ year of $\mathrm{K}_{2} \mathrm{O}$ (exchangeable $\mathrm{K}^{+}<1.6 \mathrm{mmol}_{\mathrm{c}} / \mathrm{dm}^{3}$ ) (TEIXEIRA et al., 2005b).

The average of the last three years of evaluation showed a significant effect of the combination of $\mathrm{P}$ and $\mathrm{K}$ supply on the number of coconuts/plant/year (Figure 7a) and on FAW/ha (Figure 7b). In the absence of $\mathrm{P}(0$ $\mathrm{kg} / \mathrm{ha} /$ year of $\left.\mathrm{P}_{2} \mathrm{O}_{5}\right)$ and $\mathrm{K}$ fertilization $(0 \mathrm{~kg} / \mathrm{ha} /$ year of $\mathrm{K}_{2} \mathrm{O}$ ), production was negligible. The absence of $\mathrm{K}$ fertilization limited the production, even with the maximum $\mathrm{P}$ level $\left(108 \mathrm{~kg} / \mathrm{ha} /\right.$ year of $\left.\mathrm{P}_{2} \mathrm{O}_{5}\right)$. In addition, at the highest $\mathrm{K}$ level $\left(192 \mathrm{~kg} / \mathrm{ha} /\right.$ year of $\left.\mathrm{K}_{2} \mathrm{O}\right)$ without $\mathrm{P}$ supply, plant production decreased significantly (Figures $7 \mathrm{a}$ and $7 \mathrm{~b}$ ). These results could be explained mainly by low natural soil fertility in terms of $\mathrm{P}$ and $\mathrm{K}$ in the experimental site (Table 1), requiring fertilization with both nutrients. 
A study carried out in the same region of the present study reported $\mathrm{K}$ and $\mathrm{P}$ as the nutrients that most indicated limitations in coconut plantations, using the DRIS leaf diagnosis method (SALDANHA et al., 2017). In oil palm trees, $\mathrm{K}$ fertilization was more efficient in the production of bunches under $\mathrm{P}$ fertilization (PACHECO et al., 1984). The coconut tree extracts $\mathrm{P}$ and $\mathrm{N}$ from the soil at great amounts, contributing to the formation of roots and fruits, as well as to stem thickening (OUVRIER, 1990), providing greater responses in terms of fruit quality (SILVA et al., 2006). However, the application of high K levels should be reviewed, considering the low recovery of K applied (RIBEIRO et al., 2011). K supply increased the production of dwarf coconut palm cultivated in the state of São Paulo (TEIXEIRA et al., 2005a), while its application $(346 \mathrm{~kg} / \mathrm{ha} /$ year $)$ in the Brazilian Northeast provided the highest average weight of fruits $(2.23 \mathrm{~kg})$ of the coconut tree (SILVA et al., 2006).

$\mathrm{Mg}$ fertilization did not increase production variables during 10 years of evaluation (Figure 5). Throughout the experimental period, the average yield of coconuts/plant/year (Figure 5a), FAW/coconut (Figure 5b), and FAW/ha/year (except for the $12^{\text {th }}$ year) (Figure 5c) were statistically equal between treatments. Fertilizations carried out with $\mathrm{Mg}$ along the years increased leaf $\mathrm{Mg}$ concentrations way above its critical level (Figure 3b), favoring the absence of positive response of plants under production to $\mathrm{Mg}$ application (Figure 5). In Pará State, the application of $24 \mathrm{~kg} / \mathrm{ha} /$ year of $\mathrm{Mg}$ is recommended considering 160 plants/ha for plants with leaf $\mathrm{Mg}$ concentrations of $1.4-1.8 \mathrm{~g} \mathrm{~kg}^{-1}$ (LINS and VIEGAS, 2020).

Although isolated $\mathrm{Mg}$ fertilization did not influence coconut production, it had a significant effect on FAW/ha under $\mathrm{K}$ fertilization (Figure 7c). In the absence of $\mathrm{K}$ application $\left(0 \mathrm{~kg} / \mathrm{ha} /\right.$ year of $\left.\mathrm{K}_{2} \mathrm{O}\right)$, $\mathrm{Mg}$ fertilization did not increase FAW/ha, whereas $\mathrm{Mg}$ supply (44 and $88 \mathrm{~kg} / \mathrm{ha} /$ year of $\mathrm{MgO}$ ) showed greater production with the $\mathrm{K}$ fertilization (96 and 192 $\mathrm{kg} / \mathrm{ha} /$ year of $\mathrm{K}_{2} \mathrm{O}$ ). $\mathrm{K}$ excess could affect, positively or negatively, the absorption of other cations by the plants, as they are competing directly for the same site of the carrier, such as the depressive effect of $\mathrm{K}$ on Mg (MEURER et al., 2018). Mg deficiency could be induced by excessive $\mathrm{K}$ fertilization, increasing the $\mathrm{K} /$ $\mathrm{Mg}$ ratio. However, in $\mathrm{K}$-deficient soils, condition of the current study (Table 1), K addition as fertilizer can lead to greater $\mathrm{Mg}$ absorption, which is accompanied by an increase in DM production (LIMA et al., 2018). $\mathrm{Mg}$ effect on production increase could reach $40 \%$; however, this is only possible under $\mathrm{K}$ fertilization (IRHO, 1989).
In the $11^{\text {th }}$ year of the plants, on average, the number of coconuts/plant remained at 87.6, rising to 92 coconuts in the $12^{\text {th }}$ year, and then falling to 62.7 coconuts in the $13^{\text {th }}$ year. The difference in yield observed between the years evaluated was attributed to the water deficit in the region during the $12^{\text {th }}$ year (Figure 1), reflecting on the yield of the following year. According to IRHO (1989), yield, rainfall, and water deficiency have a good relationship. Rainfall and yield curves are similar, while water deficiency reduces yield in the following year (MANCIOT et al., 1980). High temperatures and increased rainfall accelerate the leaf emission rate, allowing greater yield of coconut fruit (RIBEIRO et al., 2016). 

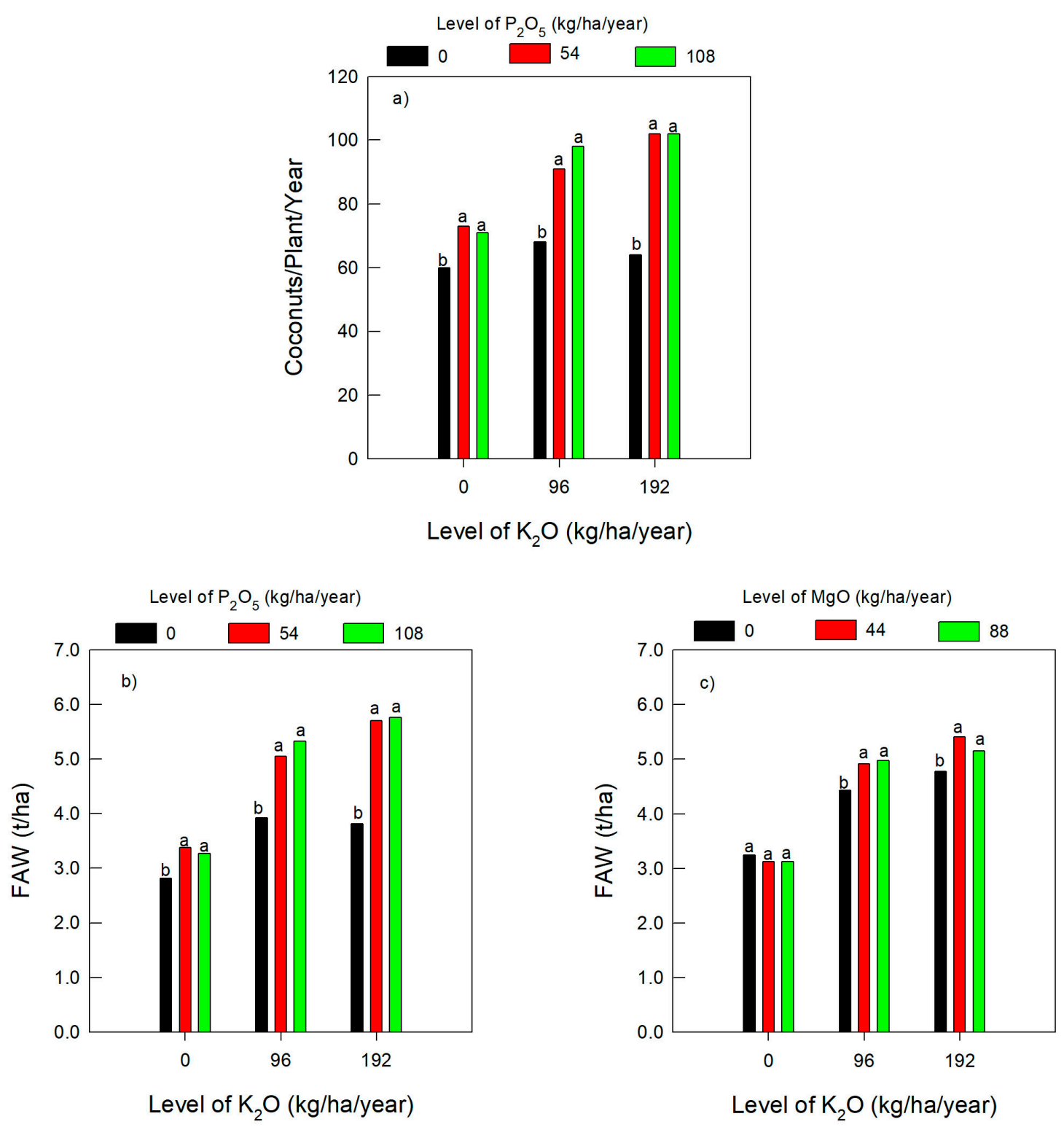

Figure 7. Effects of combinations of phosphorus and potassium fertilizations on production of coconuts/plant/year (a) and on production of fresh albumen weight-FAW/ha (b) and magnesium and potassium fertilizations on FAW/ha (c) in coconut trees $(11,12$, and 13 years old). Means, comparing the variables between the levels of each nutrient in each supply of other, followed by the same letters in the columns are considered statistically equal by the Tukey test $(\mathrm{p}>0.05)$.

\section{Conclusion}

Applications of $\mathrm{N}$ do not increase nutrient concentrations in the coconut leaf, while the application of $\mathrm{P}$ increases the $\mathrm{P}, \mathrm{Ca}$, and $\mathrm{Mg}$ concentrations and decreases the $\mathrm{K}$ concentrations. Potassium fertilization increases $\mathrm{K}$ and $\mathrm{Cl}$ concentrations and decreases $\mathrm{Ca}, \mathrm{Mg}$, and $\mathrm{B}$ concentrations, while $\mathrm{Mg}$ fertilization increases $\mathrm{Mg}$ concentrations and decreases $\mathrm{K}$ and $\mathrm{Ca}$ concentrations in the leaves;

The coconut trees were well nourished in most years in terms of $\mathrm{N}, \mathrm{Mg}$, and $\mathrm{S}$ concentrations, but not for $\mathrm{P}, \mathrm{K}, \mathrm{Ca}, \mathrm{B}$, and $\mathrm{Cl}$ concentrations;
$\mathrm{P}$ and $\mathrm{K}$ applications increase the number of coconuts/plant and fresh albumen weight (FAW/ha/ year). In the production phase (from the $6^{\text {th }}$ year of plant age), levels of $54 \mathrm{~kg} / \mathrm{ha} /$ year of $\mathrm{P}_{2} \mathrm{O}_{5}$ and $96 \mathrm{~kg} /$ ha/year of $\mathrm{K}_{2} \mathrm{O}$ are indicated for coconut cultivation in the region of Moju, Pará State, Brazil;

Nitrogen fertilization does not influence yield and $\mathrm{Mg}$ supply increases production in the presence of $\mathrm{K}$ fertilization. 


\section{References}

ABREU, C.A.; LOPES, A.S.; SANTOS, G.C.G. Micronutrientes. In: NOVAIS, R.F.; ALVAREZ, V.H.; BARROS, N.F.; FONTES, R.L.F.; CANTARUTTI, R.B.; NEVES, J.C.L. Fertilidade do solo. Viçosa: SBCS, 2007. p.645-736.

BETTER CROPS INTERNATIONAL. International plant problems insights: potassium and boron deficiencies in oil palm. Norcross: Potash and Phosphate Institute, 1989.

BRAINER, M.S.C.P. Produção de coco: o Nordeste é destaque nacional. Fortaleza: ETENE/ Banco do Nordeste, 2018. (Caderno Setorial, 61)

BROWN, P.H.; HU, H. Manejo do boro de acordo com a sua mobilidade nas diferentes culturas. Piracicaba: POTAFÓS, 1998. (Informações Agronômicas, 48)

CANTARELLA, H. Nitrogênio. In: NOVAIS, R.F.; ALVAREZ, V.H.; BARROS, N.F.; FONTES, R.L.F.; CANTARUTTI, R.B.; NEVES, J.C.L. Fertilidade do solo. Viçosa: SBCS, 2007. p.376-449.

DECHEN, A.R.; NACHTIGALL, G.R.; CARMELLO, Q.A.C.; SANTOS, L.A.; SPERANDIO, M.V.L. Micronutrientes. In: FERNANDES, M.S.; SOUZA, S.R.; SANTOS, L.A. Nutrição mineral de plantas. 2.ed. Viçosa: SBCS, 2018. p.491-562.

FAOSTAT. Food and Agriculture Organization of the United Nations. World production. Rome, 2018. Disponível em: http://faostat.fao.org/site/342/default. aspx. Acesso em: 15 abr. 2020.

FERREIRA NETO, M.; HOLANDA, J.S.; GHEYI, H.R.; FOLEGATTI, M.V.; DIAS, N.S. Atributos químicos do solo e estado nutricional de coqueiro anão fertigado com nitrogênio e potássio. Revista Caatinga, Mossoró, v.27, n.3, p.30-40, 2014.

FERREIRA, D.F. Sisvar: a computer statistical analysis system. Ciência e Agrotecnologia, Lavras, v.35, n.6, p.1039-1042, 2011.

FRÓES JÚNIOR, P.S.M.; AVIZ, W.L.C.; REBELLO, F.K.; SANTOS, M.A.S. Sources of Growth and Spatial Concentration of Coconut Crop in the State of Pará, Brazilian Amazon. Journal of Agricultural Science, Ontario, v.11, n.2, p.159-168, 2019.
IRHO - Institut de Recherches Pour les Huiles et Oléagineux. Rapport d'activité. Oléagineux, Paris, v.44, n.4, p.1- 22, 1989.

IBGE - Instituto Brasileiro de Geografia e Estatística. Anuário estatístico brasileiro. 2018. Disponível em: http://www2.sidra.ibge.gov.br/bda/tabela/listabl. asp? $\mathrm{c}=1613 \& \mathrm{z}=\mathrm{t} \& \mathrm{o}=11$. Acesso em: 15 abr. 2020.

KHAN, H.H.; BIDDAPPA, C.C.; JOSHI, O.P. A review of Indian work on phosphorus nutrition of coconut. Journal of Plantation Crops, Kasarogod, v.13, n.1, p. 11-21, 1985.

LIMA, E.; VITTI, G.C.; SANTOS, L.A.; CICARONE, F. Cálcio e magnésio. In: FERNANDES, M.S.; SOUZA, S.R.; SANTOS, L.A. Nutrição mineral de plantas. 2.ed. Viçosa: SBCS, 2018. p.465-490.

LINS, P.M.P. Resposta do coqueiro a adubação com N, P, K, Mg nas condições edafoclimáticas de MojuPA. 2000. Dissertação (Mestrado em Agronomia) Faculdade de Ciências Agrárias do Pará, Belém, 2000.

LINS, P.M.P.; VIÉGAS, I.J.M. Adubação do coqueiro no Pará. Belém: Embrapa Amazônia Oriental, 2008. (Documentos, 350)

LINS, P.M.P.; VIÉGAS, I.J.M. Coqueiro. In: BRASIL, E.C.; CRAVO, M.S.; VIÉGAS, I.J.M. Recomendações de calagem e adubação para o estado do Pará. 2.ed. Brasília: Embrapa, 2020. p.347-349.

LINS, P.M.P; NETO, J.T.F.; MULLER, A.A. Avaliação de híbridos de coqueiro (Cocos nucifera L.) para produção de frutos e de albúmen sólido fresco. Revista Brasileira de Fruticultura, Jaboticabal, v.25, n.3, p.468-470, 2003.

MAGAT, S.S. Coconut. In: IFA - International Fertilizer Association. World fertilizer use manual. 2005. Disponível em: http://www.fertilizer.org/ifa/HomePage/LIBRARY/Our-selection2/World-Fertilizer-UseManual/by-type-of-crops. Acesso em: 10 abr. 2020.

MAGAT, S.S. Fertilizer recommendations for coconut based on soil and leaf analyses. Philippine Journal of Coconut Studies, Ithaca, v.16, n.2, p.25-29, 1991.

MALAVOLTA, E.; VITTI, G.C.; OLIVEIRA, S.A. Avaliação do estado nutricional das plantas: princípios e aplicações. 2.ed. Piracicaba: POTAFÓS, 1997. 319p. 
MANCIOT, R.; OLLAGNIER, M.; OCHS, R. Nutricion mineral y fertilizacion del cocotero en la mundo. Oléagineux, Paris, v.35, n.1, p.13-27, 1980.

MATIAS, S.S.R.; AQUINO, B.F.; FREITAS, J.A.D.; HERNANDEZ, F.F.F. Análise foliar de coqueiro anão em duas épocas diferentes em relação a doses de nitrogênio e potássio. Revista Ciência Agronômica, Fortaleza, v.37, n.3, p.264-269, 2006.

MEURER, E.J.; TIECHER, T.; MATTIELLO, L. Potássio. In: FERNANDES, M.S.; SOUZA, S.R.; SANTOS, L.A. Nutrição mineral de plantas. 2.ed. Viçosa: SBCS, 2018. p.429-464.

NOVAIS, R.F.; SMYTH, T.J.; NUNES, F.N. Fósforo. In: NOVAIS, R.F.; ALVAREZ, V.H.; BARROS, N.F.; FONTES, R.L.F.; CANTARUTTI, R.B.; NEVES, J.C.L. Fertilidade do solo. Viçosa: SBCS, 2007. p.471550.

OLLAGNIER, M.; WAHYUNI, M. Mineral nutricion and fertilization of the Malayan Dwarf x West African Tall (PB-121- MAWA) hibryd coconut. Oléagineux, Paris, v.39, n., p.8-9, 1984.

OUVRIER, M. Evolution de la composition minérale du cocotier hybride PB 121 au jeune âge. Oléagineux, Paris, v.45, n.2, p.69-80, 1990.

PACHECO, A.R.; TAILLIEZ, B.J.; SOUZA, R.L.R. de; LIMA, E.J. de. Deficiências minerales de la palma aceitera (E. guineensis Jacq.) en la region de Belém do Pará, Brasil. In: MESA REDONDA LATINOAMERICANA SOBRE PALMAACEITEIRA, 2., 1984, Belém. Anais [...]. Belém: Ministério da Agricultura, 1984. p.237-268.

PEREZ, P.N.L. Crescimento, concentração e conteúdo de nutrientes em Pueraria phaseoloides L. com dois anos a oito anos de idade em Latossolo Amarelo distrófico, Tailândia, Pará. 1997. Dissertação (Mestrado em Agronomia) - Faculdade de Ciências Agrárias do Pará, Belém, 1997.

PINHO, L.G.R.; MONNERAT, P.H; PIRES, A.A.; SANTOS, A.L.A. Absorção e redistribuição de boro em Coqueiro-anão-verde. Pesquisa Agropecuária Brasileira, Brasília, DF, v.43, n.12, p.1769-1775, 2008
RIBEIRO, G.; MONNERAT, P.H.; CAMPANHARO, M.; RABELLO, W.S. Adubação potássica aplicada na axila foliar e no solo em coqueiro anão verde. Revista Ceres, Viçosa, MG, v.63, n.1, p.68-75, 2016.

RIBEIRO, G.; MONNERAT, P.H.; CAMPANHARO, M.; RABELLO, W.S. Qualidade do fruto de coqueiro anão verde em resposta à adubação potássica. Revista Caatinga, Fortaleza, v.24, n.2, p.187-191, 2011.

ROGNON, F. Cocotier. In: MARTIN-PRÉVEL, P.; GAGNARD, J.; GAUTIER, P. L'analyse végétale dans le contrôle de l'alimentation des plantes tempérées et tropicales. Paris: Tec\&Doc, 1984. p.447-57.

SALDANHA; E.C.M.; SILVA JUNIOR, M.L.; LINS, P.M.P.; FARIAS, S.C.C.; WADT, P.G.S. Nutritional diagnosis in hybrid coconut cultivated in northeastern Brazil through Diagnosis and Recommendation Integrated System (DRIS). Revista Brasileira de Fruticultura, Jaboticabal, v.39, n.1, p.1-9, 2017.

SECRETARIA, M.I.; MARAVILLA, J.N. Response of hybrid coconut palms to application of manures and fertilizers from field-planting to full-bearing stage. Plantations Recherche Développement, Montpellier, v.4, n.2, p.126-138, 1997.

SILVA, I.R.; MENDONÇA, E.S. Matéria orgânica do solo. In: NOVAIS, R.F.; ALVAREZ, V.H.; BARROS, N.F.; FONTES, R.L.F.; CANTARUTTI, R.B.; NEVES, J.C.L. Fertilidade do solo. Viçosa: SBCS, 2007. p.275374.

SILVA, R.A.; CAVALCANTE, L.F.; HOLANDA, J.S.; PEREIRA, W.E.; MOURA, M.F.; FERREIRA NETO, M. Qualidade de frutos do coqueiro-anão verde fertirrigado com nitrogênio e potássio. Revista Brasileira de Fruticultura, Jaboticabal, v.28, n.2, p. 310-313, 2006.

SILVA, R.A.; CAVALCANTE, L.F.; PAES, R.A.; HOLANDA, J.S.; COMASSETTO, F. Avaliação do estado nutricional do coqueiro anão verde fertirrigado com nitrogênio e potássio. Revista Caatinga, Fortaleza, v.22, n.1, p.119-130, 2009.

SOBRAL, L.F. Fertirrigação do coqueiro anão verde com N e K no platô de Neópolis. In: FERTBIO, 2004, Lages. Anais [...]. Lages: UDESC/SBCS, 2004. CDROM. 
SOBRAL, L.F. Nutrição e adubação do coqueiro. In: FERREIRA, J.M.S.; WARWICK, D.R.N.; SIQUEIRA, L.A. A cultura do coqueiro no Brasil. 2.ed. Aracaju: Embrapa-CPATC, 1998. p.129-157.

SOBRAL, L.F. Nutrição e adubação. In: FONTES, H.R.; RIBEIRO, F.E.; FERNANDES, M.F. Coco: produção e aspectos técnicos. Brasília: Embrapa, 2003. p.44-52.
TEIXEIRA, L.A.J.; BATAGLIA, O.C.; BUZETTI, S.; FURLANI JUNIOR, E.; ISEPON, J.S. Adubação com NPK em coqueiro-anão-verde (Cocos nucifera L.) rendimento e qualidade de frutos. Revista Brasileira de Fruticultura, Jaboticabal, v.27, n.1, p. 120-123, 2005a.

TEIXEIRA, L.A.J.; BATAGLIA, O.C.; BUZETTI, S.; FURLANI JUNIOR, E. Recomendação de adubação e calagem para coqueiro (Cocos nucifera L.) no estado de São Paulo - $1^{\text {a }}$ Aproximação. Revista Brasileira de Fruticultura, Jaboticabal, v.27, n.3, p.519-520, 2005b. 